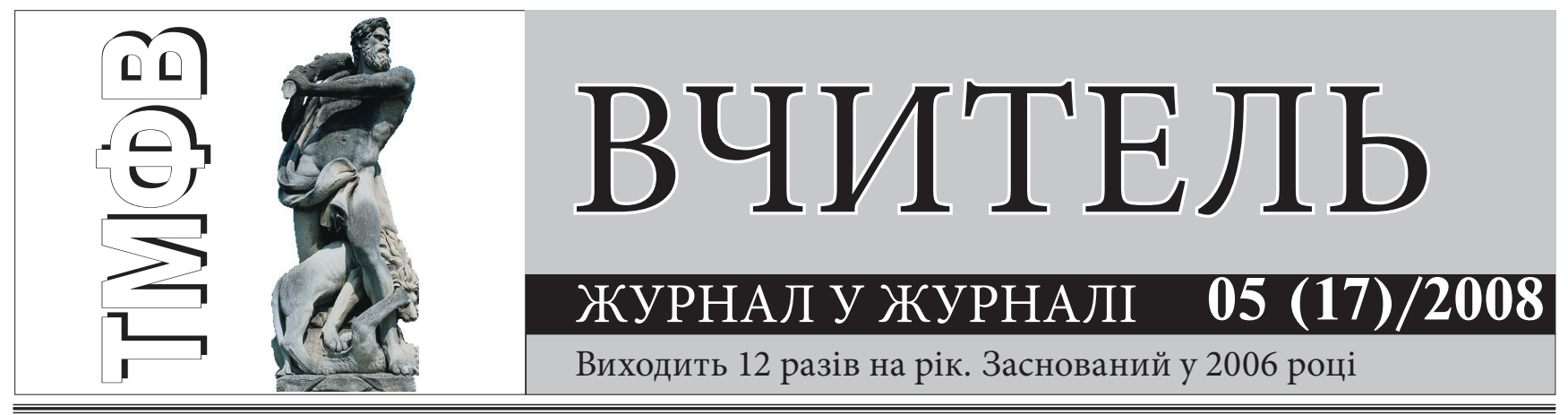

\title{
МЕТОДИКА ПЛАНУВАННЯ НАВЧАЛЬНОЇ РОБОТИ 3 ГІМНАСТИКИ В ШКОЛІ
}

\author{
Худолій О.М. \\ Харківський національний педагогічний університет імені Г.С. Сковороди
}

Анотація. У статті розкрита методика планування навчальної роботи з гімнастики в школі. Сформульовані основні вимого до упорядкування документації.

Ключові слова: планування, документи, гімнастика.

\section{Мета і завдання планування навчальної роботи}

Планування проходження навчального матеріалу - процес творчий. Вчитель складає план проходження навчального матеріалу упродовж всього року, чверті, а також кожного уроку. Останній може бути і докладним, оформленим як конспект, і менш розгорнутим, як план-конспект, i зовсім стислим. Не в формі головне. Важливо, щоб педагог зафіксував у ньому підсумок своєї підготовки до уроку, свої думки, пошуки, керуючись конкретними умовами, в яких він працює.

Мета планування - забезпечення оптимального проходження навчального матеріалу за часом i створення умов для ефективного засвоєння гімнастичних вправ і розвитку рухових здібностей.

Звичайно в методичних рекомендаціях на допомогу вчителю приводяться орієнтовні плани-графіки, але вони всього лише орієнтовні. Це означає, що викладач повинен використовувати їх з відповідними поправками на специфічні умови роботи.

Планування і облік - необхідна умова успішного ведення педагогічного процесу.

Перед планування ставляться такі основні завдання:

1. Виділити основні і підпорядковані завдання у навчанні гімнастичним вправам.

2. Виявити і усунути наявні недоліки, непослідовність в навчальній роботі.

3. Забезпечити систематичність і послідовність у роботі.
4. Забезпечити оптимальну організацію занять і визначення необхідного їх змісту.

У плані повинні бути визначені перспективи процесу навчання та виховання, а також строки виконання намічених заходів. У плануванні роботи з гімнастики необхідно враховувати контингент учнів, а також завдання та умови занять.

У залежності від завдань і специфіки колективу, планування навчальної роботи здійснюється на:

- тривалий період (перспективне планування);

- на один рік (річне);

- на короткі відрізки часу (півріччя, семестр).

Робота з гімнастики в школі планується - на півріччя, у спортивних школах - на період підготовки (підготовчий, змагальний, перехідний).

Важливо, щоб намічені планом заходи були доступні учням. Плани необхідно систематично перевіряти і контролювати їх виконання.

\section{Принципові установки до планування навчальної роботи з гімнастики в школі}

В основі планування і організації навчального процесу з гімнастики лежить програмно-цільовий підхід, у відповідності з яким визначається цільова задача і субзадачі різного рангу.

Проходження навчального матеріалу планується у відповідності зі схемою: якщо (умова) ..., то (дія) .... 
Наприклад:

1. Якщо учні 9-го класу в упорі можуть виконати 5 згинань-розгинань рук за 3,5-4,5 сек, то можливо навчання підйому махом вперед, інакше - спеціально організований процес розвитку сили.

2. Якщо учні правильно виконують упор на руках, то можливе навчання розмахуванню в упорі на руках, інакше - навчання упору на руках.

3. Якщо учні правильно виконують розмахування в упорі на руках, то можуть приступити до виконання розмахування з різною амплітудою, інакше - продовжити навчання розмахуванню.

4. Якщо учні уміють виконувати розмахування з різною амплітудою, то можуть приступити до навчання підвідним вправам.

5. Якщо учні освоїли підвідні вправи, то можуть приступити до навчання підйому махом вперед в цілому.

6. Якщо учні уміють виконувати підйом махом вперед, то необхідно виконати вправу в сполученні або комбінаціі.

Спеціально проведені дослідження дозволили сформулювати принципові установки до планування навчальної роботи з гімнастики в школі. Приницпові установки - це самостійна категорія методичних положень і правил, окремих щодо загальних принципів фізичного виховання і спортивного тренування. Вони, по-перше, розвивають керівні ідеї, укладені в цих принципах стосовно до сучасних умов, i, по-друге, виступають в якості конкретних правил програмування навчального процесу.

\section{Установка на визначення субпідрядних завдань навчання цільовій руховій дії}

У рамках навчання вирішуються завдання розвитку рухових здібностей, підвищення рівня спеціально-рухової підготовленості для засвоєння конкретних вправ. Практично це реалізується в послідовному розміщенні навчальних завдань на певному часовому відрізку. Рішення завдань і підбір серій навчальних вправ здійснюється в такій послідовності:

- розвиток рухових здібностей, які забезпечують ефективне виконання вправи, яку вивчають;

- навчання вихідним і кінцевим положенням вправи;

- навчання діям, без яких неможливо виконати вправу, що вивчається;

- навчання вмінням управляти рухами;

- навчання підвідним вправам;

- навчання вправі в сполученні або в комбінації.

\section{Установка на попередній розвиток рухових здібностей}

Послідовність, порядок розвитку рухового хисту визначається, по-перше, біологічними закономірностями розвитку організму i, по-друге, метою підготовки. Аналіз стану підготовленості, перспективи розвитку тренованості і визначення достатності їх для досягнення мети підготовки це основа технології розвитку рухових здібностей учнів.

Не секрет, що зростання сили пов’язано з фізіологічним поперечником м'язу, морфо-функціональними перебудовами на рівні ЦНС. Але є другий шлях підвищення сили - це мобілізація більшого числа мотонейронів і вдосконалення міжм'язової координації.

Якщо для виконання силової вправи достатньо сили $\mathrm{X}+\mathrm{s}$, де $\mathrm{X}$ - середнє арифметичне, s - стандартне відхилення, що характеризує коливання сили на 2-3 заняттях, то підвищення силових здібностей може проходити за рахунок вдосконалення міжм'язової координації, інакше - необхідні структурні перетворення на рівні м'язової і центрально-нервової систем. У першому випадку це досягається точним підбором рухових завдань, відповідних змагальній вправі. У другому випадку - оптимальним дозуванням силових навантажень на тривалому етапі підготовки.

\section{Наприклад:}

Для утримання «упору руки в сторони» на кільцях сила повинна бути рівна $87 \%$ від ваги тіла (дані Ю. В. Менхіна, А. В. Плоткіна). Якщо спортсмен важить 60 кг, то сила груп м'язів, що приводять, повинна бути рівна 52,2 кГ. Якщо спортсмен показує

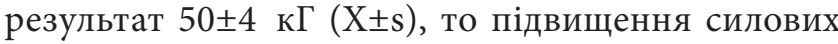
здібностей досягається за рахунок вдосконалення міжм'язової координації.

Розглянемо другий випадок розвитку силових здібностей. Для створення передумов для морфо-функціональних перебудов необхідні фізичні навантаження. Якщо фізичне навантаження викликає виснаження енергетичних ресурсів організму (порушення гомеостазу), то відбувається надлишкове відновлення і переведення організму на новий, більш високий рівень функціонування (М.М. Яковлєв, 1953, 1958, 1971; С.П. Летунов, 1966; Л.Є. Евгеньєва та ін., 1975; А.А. Віру, 1977, 1980; А.Н. Воробйов, 1977).

Під впливом фізичних навантажень у клітинах багатьох фізіологічних систем виникає одне і те саме зрушення - дефіцит багатих енергією фосфорних сполучень та збільшення потенціалу фосфорування. У свою чергу це викликає активізацію генетичного апарату клітин, посилюючи синтез нуклеїнових кислот і білків. У результаті збіль- 
шується потужність системи мітохондрій, зростає вироблення аденозінтрифосфорної кислоти (АТФ) на одиницю маси тканини і дефіцит АТФ усувається (Ф.З. Меєрсон, 1973; В. П. Скарбніков, 1980; Ю. В. Верхошанський, 1985).

Фізичні навантаження в такому випадку повинні застосовуватися так довго, як це дозволяє період поновлення білка в м'язах спортсмена. За даними Ю. В. Верхошанського (1988) строк півперіода життя білків м'язів, тобто час, за який вони наполовину оновлюють склад, - біля 30 діб. А. В. Волков (1970) стверджує, що періодичні зміни величини максимальної мускульної сили гімнастів залежать від характеру і рівня обмінних процесів, тривалість таких процесів вкладається в період рівний $13,2 \pm 1,7$ дня.

Можна припустити, що за певних умов, на протязі місяця занять фізичною культурою, можливі морфо-функціональні зміни позитивного спрямування в м’язовій і центрально-нервовій системах. Розглянемо ці умови.

У розвитку сили локальної групи м'язів слід оптимізувати навантаження і враховувати: 1) стан ЦНС; 2) скорочувальні здібності м’язів; 3) рівень енергетичного потенціалу спортсменів.

Оптимізація навантажень включає: 1) визначення величини на яку може зрости сила групи м'язів; 2) визначення впливу що неминуче приведе до зросту сили; 3 ) визначення тривалості такого впливу.

Центральна нервова система зберігає високий функціональний стан за умови, якщо силова робота виконується в першій половині заняття. Скорочувальні здібності м'язів підвищуються, якщо ЦНС не знаходиться в стадії втоми, підібраний оптимальний вплив і поперечник м'язу має тенденцію до збільшення.

Аналіз наведеного вище матеріалу дозволив припустити, що енергетичний потенціал має тенденцію до збільшення, якщо:

1) виконується силова робота в різних режимах;

2) силова робота поєднується з об'ємною роботою в одному занятті.

У результаті дослідження встановлено:

1) ефективним для розвитку максимальної сили $є$ комбінований метод;

2) швидкісно-силова робота повинна проводитися безпосередньо після підвищення максимальної сили.

\section{Методика сітьового планування навчальної роботи з гімнастики}

Технологія навчального процесу з гімнастики полягає в послідовному проходженні програмного матеріалу. Порушення технології навчального процесу веде до непослідовності у вивченні гімнастичних вправ, що подовжує час навчання. Однак програма обмежується лише переліком рухових завдань, не визначаючи порядок і тривалість вивчення різноманітних вправ.

Існує безліч варіантів вивчення одного і того самого навчального матеріалу з гімнастики. У зв'язку з цим завжди стоїть проблема вибору з цієї безлічі оптимального варіанта. Завдання значно ускладнюється трудомісткістю гімнастики, великою кількістю вправ, обмеженістю часу на їх засвоєння, недостатнім рівнем фізичної і технічної підготовленості учнів. Подолати об’єктивні труднощі за допомогою традиційного планування, основаного на практичному досвіді викладача, не завжди вдається. Реальну допомогу може надати графічний опис навчального процесу, що дасть можливість застосування математичних методів (моделей) для його планування.

Одним $з$ таких методів $є$ система сітьового планування і управління (СПУ), що дозволяє представити навчальний матеріал 3 гімнастики у вигляді графіка з наступним нескладним математичним розрахунком.

Суттєвістю сітьового моделювання єзображення комплексу запланованих робіт у вигляді графічної схеми, яка складається із заданих точок, з’єднаних лініями. Основні логічні елементи сітьового графіка - це роботи та подіï. Під дійсною роботою в гімнастиці слід розуміти будь-яку рухову дію, що вимагає витрат часу і ресурсів. До поняття "робота» відноситься і чекання - пасивний процес, що не вимагає витрат праці, фізичних зусиль, але займає час. Окрім робіт дійсних, що вимагають витрат часу і сил, існують біктивні роботи (залежності). Фіктивна робота - це логічний зв'язок між елементами, що не вимагає витрат часу і фізичної праці, але яка вказує, що можливість початку однієї роботи безпосередньо залежить від результатів іншої. Подія - підсумок зробленої роботи, проміжний або остаточний результат одного або декількох рухових завдань, що дозволить розпочати виконання наступних елементів сітьового графіка. Дійсні роботи та чекання на сітьовому графіку зображають суцільними стрілками; фіктивні - пунктирними; події - кружками, прямокутниками, квадратами або іншими геометричними фігурами з порядковими номерами. Будьяка послідовність робіт сітьового графіка, в якому кінцева подія однієї роботи співпадає з початковою подією наступної за нею, називається шляхом. Повний шлях з'єднує вихідну подію із завершальною. Найбільш тривалий з усіх повних шляхів даної сіті називається критичним (позначається жирними стрілками), (В.В. Трупан, 1980).

На рис. 1 наведений масштабний сітьовий графік навчання гімнастичним вправам учнів 9-х 


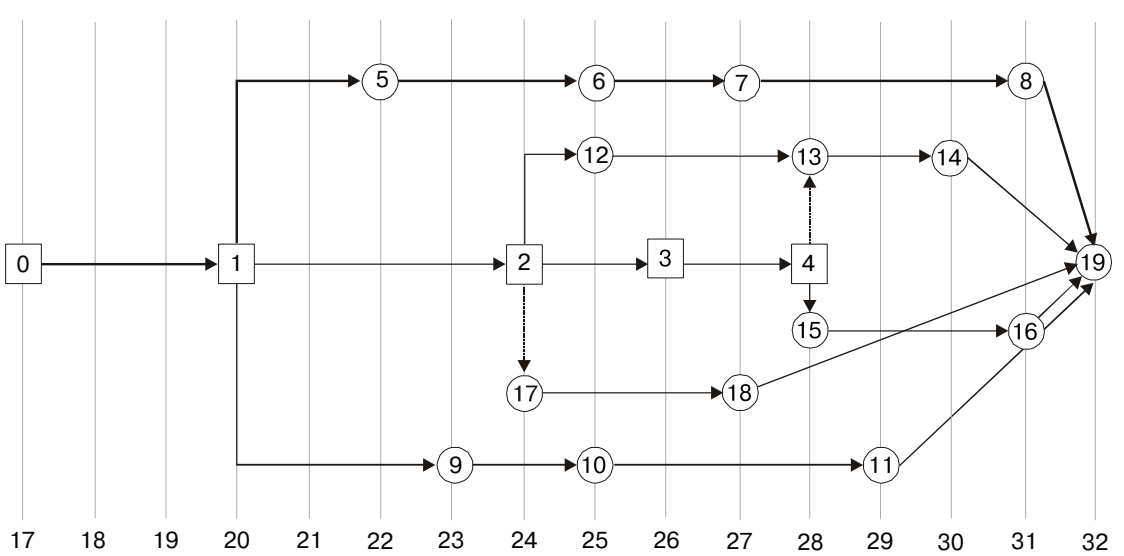

Рис. 1. Масштабний сітьовий графік навчання гімнастичним вправам учнів 9-х класів (див. табл. 1)

класів. Графік побудований на основі першої і другої принципових установок і дасть більш ясне уявлення про порядок навчання гімнастичним вправам шкільної програми.

Ключовим моментом у побудові сітьового графіка $є$ визначення найбільш складної вправи, ланки, навколо якої зв'язуються всі вправи. Такою вправою для школярів 9-х класів може бути підйом махом вперед в упор на паралельних брусах. Цей рух складний за координацією і вимагає прояву максимальних зусиль за короткий час.

Відповідно до другої установки рухова підготовленість повинна передувати навчанню рухам, тому першою виконується робота, яка спрямована на розвиток сили розгиначів передпліччя. Присвоїмо цій роботі шифр 0-1 і занесемо в таблицю вихідної інформації (див. табл. 1) такі дані:

$\begin{array}{ll}0-1 & \text { Розвиток сили м'язів плечового поясу. } \\ \text { Комбінований метод, II варіант. }\end{array}$

На масштабному сітьовому графіку відкладемо пряму і позначимо подію прямокутником 1:

Робота 0-1 погоджується з найбільш складним рухом і направлена в нашому випадку на розвиток

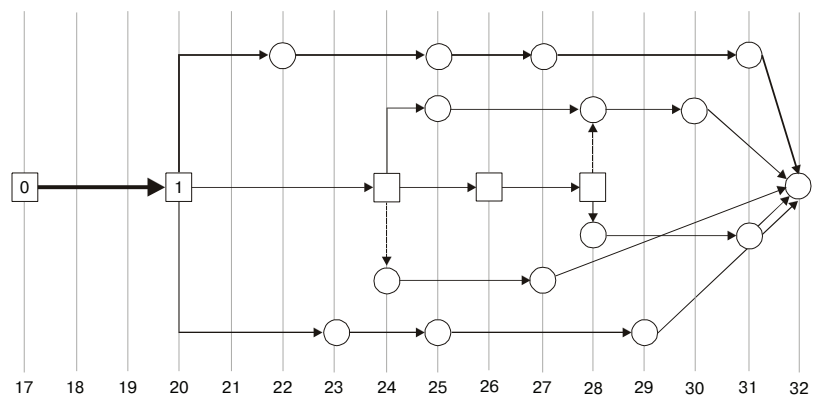

сили розгинача передпліччя. Засоби підбираються так, щоб вони мали структурну схожість з рухами, що вивчаються, і наближалися до них за характером м'язових зусиль. Для підвищення сили на 30-40\% (подія 1) використовується комбінований метод роз- витку сили, другий варіант. Силова робота організується на чотирьох послідовних станціях: I станція - метод динамічних зусиль, II станція - метод максимальних зусиль, III станція - метод ізометричних зусиль, IV станція - метод повторних зусиль.

Спеціально проведені дослідження показали ефективність такого підходу. Так, після двох тижнів занять у школярів 9-х класів збільшилася сила розгиначів передпліччя на $30-50 \%$ (О.М. Худолій, О.В. Іващенко, 1996; О.М. Худолій, А.В. Забора, 2000). Робота 0-1 продовжується 4 заняття. Заняття повністю спрямовані на розвиток сили.

Наступні роботи спрямовані на розвиток сили м'язів «спини», «рук і тулуба». Присвоїмо цій роботі шифр 1-2, в таблицю вихідної інформації впишемо:

1-2 Розвиток сили м'язів «спини», «рук і 4 уроки тулуба».

Комбінований метод, I варіант.

На масштабному сітьовому графіку з точки 1 відкладемо пряму і позначимо подію 2:

Робота $1-2$ є базовою для навчання стійці силою на голові і руках, підйому переворотом в упор.

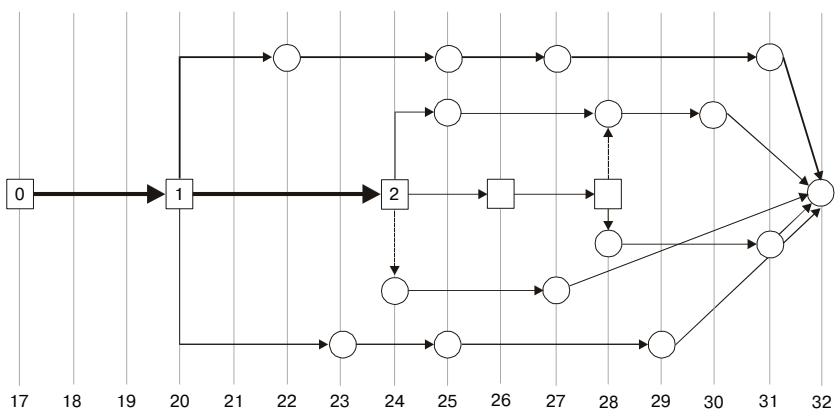

Засоби підбираються з урахуванням особливостей навчання вищезгаданим вправам. Силова робота організується на двох станціях. Тривалість роботи на кожній станції 4-6 хв. Перша станція - вправи для розвитку м'язів спини. Учні виконують пер- 
ше завдання з максимальною швидкістю, друге завдання - $з$ максимальними зусиллями, третє - 3 ізометричними зусиллями, четверте - 3 повторними зусиллями. Вправи першої станції поєднуються 3 навчанням стійці силою на голові і руках. Друга станція - вправи для рук і тулуба. Всі вправи направлені на створення умов для навчання підйому переворотом силою. Підсумком роботи $1-2 \epsilon$ достатній рівень силової підготовленості для виконання названих вправ (24 заняття).

Паралельно з роботою 1-2 продовжуємо навчання підйому махом вперед. У таблицю вихідної інформації впишемо шифр роботи $1-5$, iї назву, кількість уроків:

\section{1-5 Навчання вихідним і кінцевим поло- женням; рухи без яких неможливо ви- конання вправ.}

На масштабному сітьовому графіку відкладемо відрізок 1-5:

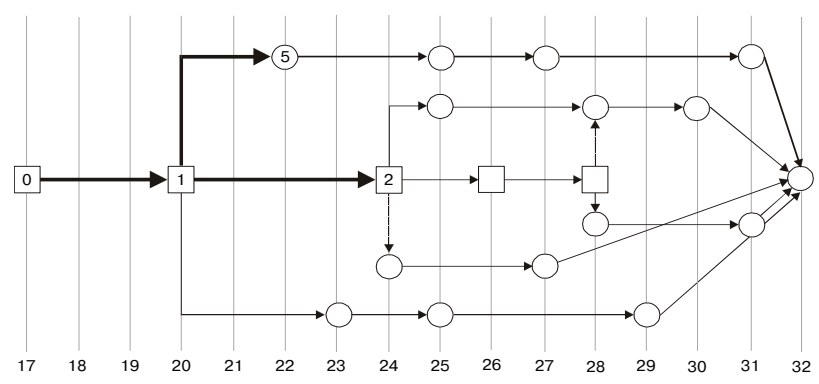

Робота $1-5$ пов'язана з II та III серією навчальних завдань навчання підйому махом вперед. Тривалість роботи 2 заняття.

3 точки 1 починається робота, спрямована на навчання умінню виконувати перекиди вперед 3 різною швидкістю. Позначимо цю роботу як $1-9$ i занесемо в таблицю наступну інформацію:

\section{1-9 Навчання умінню виконувати переки- 2 уроки ди вперед з різною швидкістю.}

1-9 На масштабному сітьовому графіку відкладемо відрізок, який відповідає роботі 1-9:

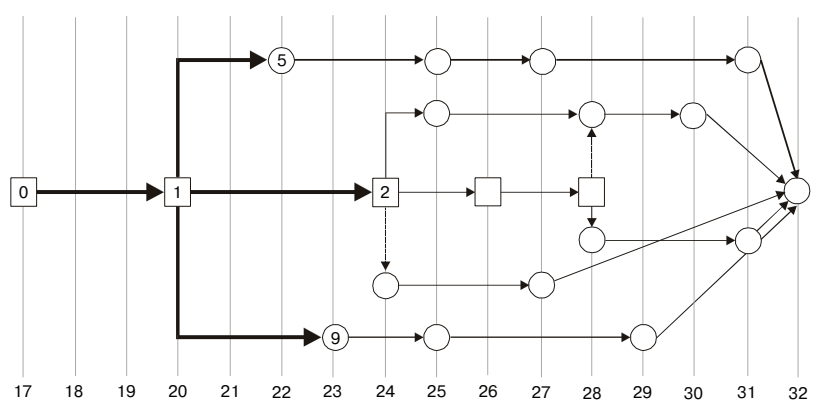

Отже роботи $1-2,1-5,1-9$ виконуються паралельно. Так як вони належать до різних струк- турних груп, то негативного перенесення навику не повинно спостерігатися.

Після досягнення події 2 переходимо до робіт 2-12 і 2-17. Аналогічно вищенаведеному в таблицю вихідної інформації вносимо шифр цих робіт і назву, а також відкладаємо відрізки на графіку (табл. 1, рис. 1). Робота 2-12 пов'язана з II серією навчальних завдань навчання стійці силою на голові, а робота 2-17 - фіктивна робота, яка вказує, що можливість початку роботи безпосередньо залежить від результатів роботи $1-2$.

Після досягнення події 2 продовжуємо роботу 3 розвитку сили (робота 2-3). Силова підготовка організується на двох станціях. Перша станція - вправи для м'язів рук, спини і ніг, що направлені на створення готовності до виконання стрибка зігнувши ноги. Друга станція - вправи для м'язів рук і тулуба, що створюють умови для відмінного виконання підйому переворотом силою.

Робота 3-4 продовжує вирішувати завдання силової підготовленості, пов'язані з ефективним виконанням стрибка зігнувши ноги і підйому переворотом силою. Роботи 17-18 та 18-19 спрямовані на оволодіння підйомом силою в упор на перекладині.

Роботи 5-6, 6-7, 7-8, 8-19 спрямовані на оволодіння підйомом махом вперед і містять засоби навчання умінням управляти рухами, підвідні вправи та вправу в цілому. Ці роботи складають найбільш тривалий шлях сіті:

Робота 5-6 триває 4 заняття, робота $6-7-2$ заняття, робота 7-8 - 4 заняття. У навчанні вправ використовується метод алгоритмічних розпоряджень, який, як відомо, дає гарні результати під час оволодінні вправами шкільної гімнастики (А.М. Шлемін).

Таким чином, сітьовий графік проходження навчального матеріалу будується на основі фізичної готовності і порядку навчання найбільш складному руху і дає можливість уникнути, по можливості, напластування складного матеріалу в одному занятті (див. рис. 1, табл. 1).

На основі сітьового графіка формулюються завдання навчання (табл. 2,), будується тематичний план-графік (табл. 3) та упорядковуються конспекти уроків (табл. 4).

\section{Основні документи планування}

\section{План роботи}

План роботи - це документ планування, що охоплює всі розділи роботи. У середніх школах його складає ст. викладач фізичного виховання. План обговорюється тими особами, що бу- 
Таблиця вихідної інформації

\begin{tabular}{|c|c|c|c|}
\hline Шифр & Робота & Попередня робота & $\begin{array}{l}\text { Кількість } \\
\text { уроків }\end{array}$ \\
\hline \multirow[t]{2}{*}{1} & 2 & 3 & 4 \\
\hline & Розвиток сили групи м'язів & & \\
\hline $0-1$ & Розвиток сили м’язів плечового поясу. Комбінований метод, II варіант & & $4(17,18,19,20)$ \\
\hline $1-2$ & $\begin{array}{l}\text { Розвиток сили м'язів «спини», «рук і тулуба». Комбінований метод, I } \\
\text { варіант }\end{array}$ & $0-1$ & $4(21,22,23,24)$ \\
\hline $2-3$ & $\begin{array}{l}\text { Розвиток сили м’язів «рук, спини і ніг», «рук і тулуба». Комбінований } \\
\text { метод, І варіант }\end{array}$ & $0-1,1-2$ & $2(25,26)$ \\
\hline \multirow[t]{2}{*}{$3-4$} & Розвиток сили м’язів «рук, спини і ніг». Комбінований метод, І варіант & $\begin{array}{l}0-1,1-2, \\
2-3\end{array}$ & $2(27,28)$ \\
\hline & Роботи спрямовані на навчання підйому махом вперед & & \\
\hline $1-5$ & $\begin{array}{l}\text { Навчання вихідним і кінцевим положенням; рухам без яких неможливо } \\
\text { виконання вправи }\end{array}$ & $0-1$ & $2(21,22)$ \\
\hline $5-6$ & Навчання умінням управляти рухами & $0-1,1-5$ & $4(22,23,24,25)$ \\
\hline $6-7$ & Навчання підвідним вправам & $0-1,1-5,5-6$ & $2(26,27)$ \\
\hline $7-8$ & Навчання вправі в цілому, у сполученні & $0-1,1-5,5-6,6-7$ & $4(28,29,30,31)$ \\
\hline \multirow[t]{2}{*}{$8-19$} & Виконання елемента в комбінації & $0-1,1-5,5-6,6-7$ & $2(31,32)$ \\
\hline & Довгий перекид вперед з трьох кроків & & \\
\hline $1-9$ & Навчання умінню виконувати перекид вперед з різною швидкістю & $0-1$ & $3(21,22,23)$ \\
\hline $9-10$ & Підвідні вправи & $1-9$ & $3(23,24,25)$ \\
\hline $10-11$ & Вправа в цілому & $9-10$ & $5(25,26,27,28,29)$ \\
\hline \multirow{2}{*}{$11-19$} & Виконання елемента в комбінації & $0-1,1-9,9-10$ & $4(29,30,31,32)$ \\
\hline & Стійка силою на голові і руках & & \\
\hline $2-12$ & $\begin{array}{l}\text { Навчання вихідним і кінцевим положенням (2 серія навчальних за- } \\
\text { вдань) }\end{array}$ & $1-2$ & $2(24,25)$ \\
\hline $12-13$ & Навчання підвідним вправам (5 серія навчальних завдань) & $1-2,2-12$ & $3(26,27,28)$ \\
\hline $4-13$ & $\begin{array}{l}\text { Фіктивна робота, яка вказує на залежність ефективності виконання } \\
\text { стійки силою від силової підготовленості м’язів спини і рук }\end{array}$ & $\begin{array}{l}1-2,2-3 \\
3-4\end{array}$ & \\
\hline $13-14$ & Виконання вправи в цілому & $\begin{array}{l}1-2,2-12,12-13,14- \\
13\end{array}$ & $3(28,29,30)$ \\
\hline \multirow[t]{2}{*}{$14-19$} & Виконання вправи в комбінації & $\begin{array}{l}1-2,2-12,2-13 \\
13-14\end{array}$ & $3(30,31,32)$ \\
\hline & Підйом переворотом силою в упор на перекладені & & \\
\hline $2-17$ & $\begin{array}{l}\text { Фіктивна робота, яка вказує, що початок роботи залежить від резуль- } \\
\text { татів роботи }\end{array}$ & $1-2$ & $1-2$ \\
\hline $17-18$ & Виконання вправи в цілому & $1-2,2-17$ & $(25,26,27)$ \\
\hline \multirow[t]{2}{*}{$18-19$} & Виконання вправи в комбінації & $1-2,2-17,17-18$ & $5(28,29,30,31,32)$ \\
\hline & Стрибок зігнувщи ноги через козла в довжину, $h=115 \mathrm{cM}$ & & \\
\hline $4-15$ & $\begin{array}{l}\text { Фіктивна робота, яка вказує на залежність навчання від швидкісно-си- } \\
\text { лової підготовки учнів }\end{array}$ & $1-2,2-3,3-4$ & \\
\hline $15-16$ & Виконання опорного стрибка в цілому & $4-15$ & $4(28,29,30,31)$ \\
\hline $16-19$ & Виконання стрибка в умовах наближених до змагань & $4-15,16-19$ & $2(31,32)$ \\
\hline
\end{tabular}

дуть брати участь в його виконанні, і затверджується директором школи.

Звичайно він складається за такою формою:

План роботи ЗОШ № на 2006/2007 навчальний рік

\begin{tabular}{|l|l|l|l|l|}
\hline $\begin{array}{l}\text { № } \\
\text { 3/п }\end{array}$ & $\begin{array}{l}\text { Найменування } \\
\text { розділів та зміст } \\
\text { роботи }\end{array}$ & $\begin{array}{l}\text { Строки } \\
\text { вико- } \\
\text { нання }\end{array}$ & $\begin{array}{l}\text { Відповідальний } \\
\text { за виконання }\end{array}$ & $\begin{array}{l}\text { Відмітка } \\
\text { про вико- } \\
\text { нання }\end{array}$ \\
\hline & & & & \\
\hline
\end{tabular}

План включає розділи з організаційної, навчально-методичної, навчально-тренувальної, виховної, лікарсько-контрольної, агітаційно-масової, фінансово-господарської роботи.

\section{Організаційна робота:}

- комплектування навчальних груп;

- підбор викладачів і розподіл обов'язків між ними;

- підготовка активу (інструкторів, суддів);

- збори, наради з організаційних питань; 
- перевірка виконання намічених заходів, звіти.

Навчально-методична робота:

- укладання навчально-методичної документації і розкладу;

- заходи, направлені на підвищення кваліфікації викладачів, тренерів (відкриті уроки, взаємовідвідування).

Навчально-тренувальна робота:

- укладання календаря спортивних заходів;

- розробка положень про змагання;

- підготовка розрядників і суддів.

Виховна робота:

- доповіді, лекції, бесіди, що мають відношення до гімнастики і виховання учнів;

- зустрічі з майстрами гімнастики, призерами різних першостей.

Лікарсько-контрольна робота:

- встановлення термінів медичних оглядів;

- проведення консультацій, спеціальних лікарських досліджень;

- повідомлення про стан здоров'я учнів.

Агітаційно-масова робота:

- проведення лекцій, показових виступів й інших заходів, спрямованих на пропаганду гімнастики серед населення.

Фінансово-господарська робота:

- оренда і ремонт гімнастичних залів;

- придбання спортивної форми, наочних посібників, обладнання, інвентарю.

У залежності від завдань і особливостей колективу розділи плану і їній зміст можуть змінюватися.

\section{Навчальний план}

Навчальний план - складається на весь термін навчання. Під час його упорядкування необхідно враховувати: 1) мету і завдання навчання; 2) підготовленість учнів; 3) вік і стан здоров'я; 4) матеріальну базу тощо.

У залежності від цього визначають:

1) кількість дисциплін, видів занять і вправ, що підлягають вивченню і послідовність їх проходження;

2) тематику теоретичного курсу;

3) на весь строк навчання кількість годин, відведених на кожну дисципліну, вид занять, вид вправ;

4) орієнтовні строки заліків, іспитів, змагань.

Навчальні плани в школі складаються на рік по семестрам.

Після складання навчального плану укладається навчальна програма.

\section{Навчальна програма}

Навчальна програма - складається на той же строк, що і навчальний план, і визначає обсяг знань, вмінь, навичок, якими повинні оволодіти учні за весь період занять. У ній визначається послідовність вивчення і планування навчального матеріалу.

Програма має таку структуру:

1. Назва програми.

2. Пояснювальна записка. У ній визначаються мета і завдання занять, даються організаційно-методичні вказівки до проходження матеріалу програми.

3. Зміст програми викладається в такій самій послідовності, як і навчальний план:

а) теоретичні теми;

б) практичний матеріал;

в) залікові вимоги;

г) література, що рекомендується.

У відмінності від навчального плану в усіх розділах перераховуються докладно вправи, що слід вивчати.

Навчальну програму складають для роботи в секціях гімнастики, а також для роботи за авторськими програмами. У плануванні змісту уроків фізичної культури використовують державну комплексну програму загальноосвітньої школи. Державна програма може використовуватися як зразок для складання авторських програм.

\section{Тематичний план-графік}

Тематичний план-графік - конкретизує навчальний план і програму. Він складається на підставі навчального плану, програми і визначає:

1) зміст навчального матеріалу;

2) послідовність навчання вправам;

3) взаємозв'язок уроків фізичної культури;

4) систему контрольних уроків.

Тематичний план-графік упорядковується за розділами навчального плану.

\section{Робочий план}

Робочий план - систематизоване викладення навчального матеріалу програми, детально розробленого і розташованого в порядку зростаючої трудності. Робочий план - це детальне планування ходу і результатів навчального процесу. Складається він на невеликі періоди часу на підставі графіка навчального плану для кожного класу.

У ньому визначаються:

1) кількість вправ, тематика теоретичного, методичного і практичного курсів, що підлягають вивченню за вказаний період;

2) кількість повторень кожного виду вправ;

3) послідовність проходження навчального матеріалу; 
4) точні строки заліків, контрольних занять, змагань.

\section{План-конспект уроку}

План-конспект уроку найбільш повно розкриває зміст, методику та організацію кожного заняття. Конспект містить задачі уроку, тривалість його частин, чергування видів, їх зміст та дозування. Вправи підготовчої частини підбираються згідно змісту основної частини. У складанні конспекту уроку необхідно враховувати результати попередніх уроків і вносити відповідні корективи.

Конспект уроку упорядковується на підставі тематичного плану-графіка.

\section{Практичне керівництво: складаємо документи для 9-го класу}

\section{Складаємо річний план}

Теоретичні відомості:
Юнаки: рівновага на одній нозі - упор стоячи ноги нарізно і силою стійка на голові - опускання в упор присівши - перекид назад - встати і стрибком поворот кругом - 3 двох-трьох кроків розбігу довгий перекид вперед - стрибок вверх прогнувшись - основна стійка.

Дівчата: зі стійки ноги нарізно нахилом назад «міст» 3 допомогою - поворот кругом в упор присівши - перекид назад - перекатом назад стійка на лопатках - перекид назад через плече в напівшпагат - упор присівши і встати - кроком вперед рівновага на одній нозі - випад - перекид вперед - стрибок вверх прогнувшись - основна стійка.

\section{2. Опорний стрибок}

Юнаки: зігнувши ноги (козел у довжину, висота $115 \mathrm{~cm})$.

Дівчата: боком (кінь у ширину, висота 110 см).

\section{3. Бруси}

Юнаки: розмахування в упорі на руках і махом вперед підйом у сід ноги нарізно - перекид вперед у сід ноги нарізно - кут в упорі (тримати) - махом

Річний навчальний план для учнів 9 класів

\begin{tabular}{|l|c|c|c|c|c|}
\hline \multirow{2}{*}{\multicolumn{1}{c|}{ Розділ }} & \multirow{2}{*}{$\begin{array}{c}\text { Кількість } \\
\text { уроків }\end{array}$} & $\begin{array}{c}|c| \\
\text { I семест }\end{array}$ & \multicolumn{2}{c|}{ II семестр } \\
\cline { 3 - 6 } & & $\begin{array}{c}\text { II чверть } \\
19-32\end{array}$ & $\begin{array}{c}\text { III чверть } \\
33-52\end{array}$ & $\begin{array}{c}\text { IV чверть } \\
53-68\end{array}$ \\
\hline Теоретичні відомості & & \multicolumn{2}{|c|}{ У процесі навчальних занять } \\
\hline Легка атлетика & 20 & 10 & & & 10 \\
\hline Гімнастика & 16 & 2 & 14 & & 6 \\
\hline Спортивні ігри & 16 & 6 & & 4 & 16 \\
\hline Лижна підготовка & 16 & & & 20 & 16 \\
\hline Всього & 68 & 18 & 14 & & \\
\hline
\end{tabular}

1. Вплив занять фізичними вправами на основні системи організму.

2. Лікарський контроль.

3. Правила самостійного виконання вправ спрямованих на розвиток витривалості.

4. Правила самоконтролю і безпеки під час виконання вправ.

5. Руховий режим учнів. назад зігнути руки - махом вперед розігнути руки (двічі) - махом назад зіскок.

Дівчата: вис прогнувшись на н.ж. з опорою ногами об в.ж. і переворот в упор на н.ж. - перемах правою з перехватом правою рукою за в.ж. хватом знизу - поворот наліво кругом з перемахом правою у вис лежачи на н.ж. - сід на лівому стегні, правую руку в сторону - сід кутом з опорою пра-

Навчальні нормативи:

\begin{tabular}{|c|c|c|c|c|c|c|c|}
\hline \multirow{3}{*}{$\begin{array}{l}\text { № } \\
3 / \Pi\end{array}$} & \multirow{3}{*}{ Контрольні вправи } & \multicolumn{6}{|c|}{ Нормативи } \\
\hline & & \multicolumn{3}{|c|}{ Юнаки } & \multicolumn{3}{|c|}{ Дівчата } \\
\hline & & 5 & 4 & 3 & 5 & 4 & 3 \\
\hline \multirow[b]{2}{*}{1} & «Підтягування» в висі & 10 & 8 & 7 & - & - & - \\
\hline & $\begin{array}{l}\text { Піднімання тулуба з поло- } \\
\text { ження лежачи на спині, руки } \\
\text { за головою }\end{array}$ & & & & 20 & 15 & 10 \\
\hline 2 & $\begin{array}{l}\text { Лазіння по канату без допо- } \\
\text { моги ніг, м }\end{array}$ & 5 & 4 & 3 & - & - & - \\
\hline
\end{tabular}

Навчальні комбінації: 1. Акробатика вою рукою ззаду - встати на правій в стійку на н.ж. - рівновага на правій - приставляючи ліву, 
поворот наліво - стрибком упор на в.ж. - опускання переворотом вперед в вис - мах назад і махом вперед зіскок.

\section{4. Перекладина}

Юнаки: підйом переворотом в упор силою опускання переворотом вперед у вис - вис кутом (тримати) - розмахування вигинами - зіскок махом назад з поворотом наліво (праворуч).

\section{5. Колода}

3 невеликого розбігу вскок у сід на стегно - сід кутом з опорою руками ззаду - розводячи ноги нарізно і відводячи їх назад, упор лежачи на зігнутих руках - випрямити руки - поштовхом ніг упор присівши - встати, руки в сторони - ходьба на носках - напівприсід і поворот кругом на носках - стрибки на лівій, права спереду-донизу - те саме на правій - кроком лівої рівновага - зіскок прогнувшись 3 кінця колоди кроком вперед.

\section{Плануємо проходження навчального матеріалу}

Узагальнена мета занять гімнастикою в школі розвиток, освіта, виховання школярів. Від поставлених завдань уроку залежить підбір рухових завдань. У різних методичних рекомендаціях стверджується, що в уроці повинно бути три завдання, які тісно зв’язані з узагальненою метою. Це вірно, але кількість завдань залежить від можливості дроблення навчального матеріалу, від логічного зв'язку окремих уроків. Сітьовий графік розподілення навчального матеріалу дозволяє поставити коректні завдання до кожного уроку, уникнути надмірного дроблення матеріалу, а також виникнення ситуації негативного переносу рухової навички. Важливе значення у формулюванні завдань уроку має також і підбір методів розвитку рухових здібностей і навчання. Використання комбінованого методу розвитку сили, методу алгоритмічних розпоряджень для навчання вправам дозволяє деталізувати завдання уроку, зробити їх доступними для реалізації.

На підставі таблиці вихідної інформації (див. табл. 1) сформулюємо завдання і запишемо їх y таблицю 2.

Таблиця 2

Навчальні завдання для учнів 9-х класів

\begin{tabular}{|c|c|}
\hline $\begin{array}{c}\text { № } \\
\text { уроку }\end{array}$ & Завдання уроку \\
\hline 1 & 2 \\
\hline 17 & $\begin{array}{l}\text { 1. Навчити загальнорозвиваючим вправам у русі } \\
\text { (комплекс 1). } \\
\text { 2. Навчити загальнорозвиваючим вправам у па- } \\
\text { рах (комплекс 4). } \\
\text { 3. Сприяти розвитку функції рівноваги. } \\
\text { 4. Сприяти розвитку сили м’язів плечового поя- } \\
\text { су. }\end{array}$ \\
\hline $18-20$ & $\begin{array}{l}\text { 1. Сприяти розвитку функції рівноваги. } \\
\text { 2. Сприяти розвитку сили м'язів плечового поя- } \\
\text { су. }\end{array}$ \\
\hline
\end{tabular}

\begin{tabular}{|c|c|}
\hline 21 & $\begin{array}{l}\text { 1. Навчити загальнорозвиваючим вправам на } \\
\text { місці (комплекс 3). } \\
\text { Юнаки: } \\
\text { 2. Сприяти розвитку спеціальної рухової підго- } \\
\text { товленості учнів для виконання: } \\
\text { а) підйому переворотом силою; } \\
\text { б) опорного стрибка зігнувши ноги; } \\
\text { в) стійці силою на голові; } \\
\text { г) підйому махом вперед. } \\
\text { 3. Повторити перекиди вперед } 3 \text { різною швидкіс- } \\
\text { тю. } \\
\text { Дівчата: } \\
\text { 1. Навчити вису прогнувшись на н.ж., з опорою } \\
\text { стопами об в.ж. і переходу в упор на н.ж. } \\
\text { 2. Навчити на р/в брусах зіскоку із сіду на стегні. } \\
\text { 3. Повторити акробатичні вправи. } \\
\text { 4. Повторити стрибок боком. }\end{array}$ \\
\hline 22 & $\begin{array}{l}\text { Юнаки: } \\
\text { 1. Сприяти розвитку спеціальної рухової підго- } \\
\text { товленості учнів для виконання: } \\
\text { а) підйому переворотом силою; } \\
\text { б) опорного стрибка зігнувши ноги; } \\
\text { в) стійці силою на голові. } \\
\text { 2. Навчити підйому махом вперед: друга і третя } \\
\text { серії навчальних завдань. } \\
\text { Дівчата: } \\
\text { 1. Повторити акробатичні вправи. } \\
\text { 2. Повторити опорний стрибок боком. } \\
\text { 3. Навчити вису прогнувшись на н.ж., з опорою } \\
\text { стопами об в.ж. і переходу в упор на н.ж. }\end{array}$ \\
\hline 23 & $\begin{array}{l}\text { Юнаки: } \\
\text { 1. Сприяти розвитку спеціальної рухової підго- } \\
\text { товленості учнів для виконання: } \\
\text { a) стійки силою на голові і руках; } \\
\text { б) підйому переворотом силою. } \\
\end{array}$ \\
\hline & $\begin{array}{l}\text { 2. Навчити підйому махом вперед: четверта серія } \\
\text { навчальних завдань. } \\
\text { 3. Навчити довгому перекиду вперед з трьох кро- } \\
\text { ків: підвідні вправи. } \\
\text { 4. Навчити стрибку зігнувши ноги через козла: } \\
\text { третя серія навчальних завдань. } \\
\text { Дівчата: } \\
\text { 1. Повторити акробатичні вправи. } \\
\text { 2. Повторити опорний стрибок боком. } \\
\text { 3. Повторити вправи на р/в брусах. }\end{array}$ \\
\hline 24 & $\begin{array}{l}\text { Юнаки: } \\
\text { 1. Навчити підйому переворотом в упор силою. } \\
\text { 2. Навчити підйому махом вперед: четверта серія } \\
\text { навчальних завдань. } \\
\text { 3. Навчити стійці силою на голові і руках: друга } \\
\text { серія навчальних завдань. } \\
\text { 4. Навчити довгому перекиду вперед з трьох кро- } \\
\text { ків: підвідні вправи. } \\
\text { 5. Навчити стрибку зігнувши ноги через козла: } \\
\text { третя серія навчальних завдань. } \\
\text { Дівчата: } \\
\text { ті самі завдання, що на } 23 \text { уроці. }\end{array}$ \\
\hline 25 & $\begin{array}{l}\text { Юнаки: } \\
\text { 1. Навчити підйому переворотом в упор силою. } \\
\text { 2. Навчити підйому махом вперед: четверта серія } \\
\text { навчальних завдань. } \\
\text { 3. Навчити стійці силою на голові і руках: підвідні } \\
\text { вправи. } \\
\text { 4. Навчити довгому перекиду вперед з трьох кро- } \\
\text { ків. } \\
\text { 5. Навчити стрибку зігнувши ноги через козла: } \\
\text { третя серія навчальних завдань. } \\
\text { Дівчата: } \\
\text { ті самі завдання, що на } 24 \text { уроці. }\end{array}$ \\
\hline
\end{tabular}




\begin{tabular}{|c|c|}
\hline 26 & $\begin{array}{l}\text { Юнаки: } \\
\text { 1. Навчити підйому переворотом в упор силою. } \\
\text { 2. Навчити підйому махом вперед: п’ята серія } \\
\text { навчальних завдань. } \\
\text { 3. Навчити стійці силою на голові і руках: підвідні } \\
\text { вправи. } \\
\text { 4. Навчити довгому перекиду вперед } 3 \text { трьох кро- } \\
\text { ків. } \\
\text { 5. Навчити стрибку зігнувши ноги через козла: } \\
\text { третя серія навчальних завдань. } \\
\text { Дівчата: } \\
\text { ті самі завдання, що на } 25 \text { уроці. }\end{array}$ \\
\hline \multirow[t]{2}{*}{27} & $\begin{array}{l}\text { Юнаки: } \\
\text { 1. Навчити підйому махом вперед: підвідні впра- } \\
\text { ви. } \\
\text { 2. Навчити стійці силою на голові і руках: п'ята } \\
\text { серія навчальних завдань. }\end{array}$ \\
\hline & $\begin{array}{l}\text { 3. Навчити стрибку зігнувши ноги через козла: } \\
\text { третя серія навчальних завдань. } \\
\text { 4. Повторити раніше вивчені вправи. } \\
\text { Дівчата: } \\
\text { ті самі завдання, що на } 26 \text { уроці. }\end{array}$ \\
\hline 28 & $\begin{array}{l}\text { Юнаки: } \\
\text { 1. Навчити стійці силою на голові. } \\
\text { Далі ті самі завдання, що на } 27 \text { уроці. } \\
\text { Дівчата: } \\
\text { ті самі завдання, що на } 27 \text { уроці. }\end{array}$ \\
\hline \multirow[t]{2}{*}{29} & $\begin{array}{l}\text { Юнаки: } \\
\text { 1. Навчити підйому махом вперед. } \\
\text { 2. Навчити стійці силою на голові і руках. } \\
\text { 3. Навчити стрибку зігнувши ноги: п’ята серія } \\
\text { навчальних завдань }\end{array}$ \\
\hline & $\begin{array}{l}\text { 4. Повторити раніше вивчені вправи. } \\
\text { Дівчата: } \\
\text { 1. Повторити раніше вивчені вправи. }\end{array}$ \\
\hline 30 & $\begin{array}{l}\text { Юнаки: } \\
\text { 1. Навчити підйому махом вперед. } \\
\text { 2. Навчити стрибку зігнувши ноги: п’ята серія } \\
\text { навчальних завдань. } \\
\text { 3. Повторити раніше вивчені вправи. } \\
\text { Дівчата: } \\
\text { 1. Повторити раніше вивчені вправи. }\end{array}$ \\
\hline $31-32$ & $\begin{array}{l}\text { 1. Виконати на оцінку контрольні вправи і нав- } \\
\text { чальні комбінації. }\end{array}$ \\
\hline
\end{tabular}

Деталізуємо зміст сітьового графіка проходження навчального матеріалу і визначимо засоби для вирішення завдань уроку. Для цього складемо тематичний план-графік.

У тематичний план-графік (див. табл. 3) внесемо всі вправи, які вивчаються в дев'ятому класі. Для кожної вправи складемо навчальну програму типу алгоритмічних розпоряджень. Під кожною вправою запишемо серії навчальних завдань. Вправи розташуємо в порядку складності. На основі сітьвого графіка визначимо порядок і строки виконання серій навчальних завдань. Вправи серій навчальних завдань підбираються так, щоб учні змогли їх засвоїти на одному уроці. Напроти вправи, в графі номера уроку позначаємо навчання («н»), якщо вправу виконуємо перший раз, або повторення («п»), якщо вправа виконувалася на попередньому уроці. Для розвитку сили окремих груп м'язів використаємо за- соби, які рекомендуються програмою, а також перші серії навчальних завдань вправ, які вивчаються.

Міцність рухової навички в гімнастиці визначається можливістю виконання вивченої вправи у сполученні, у комбінації. У тематичному плані передбачимо, після оволодіння програмним матеріалом, виконання комбінацій на кожному снаряді. Останні два уроки присвячуємо контролю за оволодінням програмним матеріалом. Для цього заплануємо виконання комбінацій і навчальних нормативів, і відповідно в графах номера уроків поставимо позначку контролю («К»).

\section{Складаємо комплекси загальнорозвиваючих вправ}

На уроках фізичної культури загальнорозвиваючі вправи виконуються у вигляді окремих вправ, серії вправ і спеціально упорядкованих комплексів.

Під час складання комплексів визначається обсяг і зміст вправ, що будуть включені до них. Для комплексів підготовчої частини необхідно підібрати 8-15 вправ.

Вправи підбираються з урахуванням:

- завдань основної частини уроку;

- всебічного впливу на всі групи м'язів, органи і системи організму;

- формування правильної постави і уміння оцінювати рухи в просторі, за часом i м'язовими зусиллями;

- доступності і відповідності змісту навчальної програми.

Вправи рекомендується включати в комплекс у такій послідовності:

1. Першою в комплексі повинна бути вправа на відчуття правильної постави (цією вправою повинен починатися і закінчуватися комплекс). Це важливо тому, що створюється настанова на збереження правильної постави у виконанні наступних вправ.

2. Другими і третіми повинні бути прості вправи, але в виконанні яких зайняті великі групи м'язів всього тіла (ходьба на місці із високим підніманням ніг, присідання з нахилом уперед і рухами руками, випади із нахилами та ін.). Ці вправи загального впливу активізують діяльність всіх органів і систем організму, що дуже важливо для підготовки організму до наступної роботи.

3. Наступними в комплексі повинні бути вправи з переважною роботою різних груп м'язів (рук і плечового поясу, тулуба і ніг). Ці вправи описані вище.

При цьому в роботу повинні включатися послідовно різні частини тіла. Перша серія вправ виконується в такому порядку - вправи для рук і плечового поясу, спини і черевного преса, ніг. Друга 
Тематичний план-графік проходження навчального матеріалу з гімнастики для учнів 9-х класів

\begin{tabular}{|c|c|c|c|c|c|c|c|c|c|c|c|c|c|c|c|c|c|}
\hline № & \begin{tabular}{|l|} 
3міст \\
\end{tabular} & 17 & 18 & 19 & 20 & 21 & 22 & 23 & 24 & 25 & 26 & 27 & 28 & 29 & 30 & 31 & 32 \\
\hline 1 & Основи знань & + & + & + & + & + & + & + & + & + & + & + & + & + & + & + & + \\
\hline 2 & Стройові вправи: & & & & & & & & & & & & & & & & \\
\hline & а) перестроювання в русі; & п & $\Pi$ & $\Pi$ & п & $\Pi$ & $\Pi$ & п & п & $\Pi$ & $\Pi$ & п & $\Pi$ & $\Pi$ & $\Pi$ & п & п \\
\hline & б) рух до точок залу; & $\Pi$ & $\Pi$ & $\Pi$ & $\Pi$ & $\Pi$ & $\Pi$ & $\Pi$ & $\Pi$ & $\Pi$ & $\Pi$ & $\Pi$ & $\Pi$ & $\Pi$ & $\Pi$ & $\Pi$ & $\Pi$ \\
\hline & в) рухи протиходом, «змійкою» & п & $\pi$ & п & $\Pi$ & $\Pi$ & п & п & $\pi$ & $\pi$ & п & п & $\Pi$ & $\pi$ & $\pi$ & $\pi$ & $\Pi$ \\
\hline 3 & Загальнорозвиваючі вправи: & & & & & & & & & & & & & & & & \\
\hline & a) y pyci $(№ 1,2)$ & $\mathrm{H}$ & $\Pi$ & $\Pi$ & $\Pi$ & $\Pi$ & $\Pi$ & $\Pi$ & $\Pi$ & $\mathrm{H}$ & $\Pi$ & $\Pi$ & $\Pi$ & $\Pi$ & $\Pi$ & $\Pi$ & $\Pi$ \\
\hline & 6) на місці (№ 3); & & & & & $\mathrm{H}$ & $\Pi$ & $\Pi$ & п & $\Pi$ & $\Pi$ & $\Pi$ & $\Pi$ & $\Pi$ & $\Pi$ & п & $\Pi$ \\
\hline & в) у парах (№ 4) & $\mathrm{H}$ & $\Pi$ & $\Pi$ & $\Pi$ & & & & & & & & & & & & \\
\hline 4 & Виси і упори: & & & & & & & & & & & & & & & & \\
\hline & Юнаки & & & & & & & & & & & & & & & & \\
\hline & Перекладина: & & & & & & & & & & & & & & & & \\
\hline & із вису підйом переворотом в упор силою & & & & & + & + & + & + & + & + & + & & & & & \\
\hline- & із вису на зігнутих руках вис прогнувшись; & & & & & $\mathrm{H}$ & п & $\Pi$ & $\Pi$ & $\Pi$ & п & & & & & & \\
\hline - & із положення лежачи на перекладині упор; & & & & & $\mathrm{H}$ & $\Pi$ & $\Pi$ & $\Pi$ & $\Pi$ & п & & & & & & \\
\hline- & підйом переворотом в упор з допомогою; & & & & & & $\mathrm{H}$ & $\mathrm{H}$ & $\mathrm{H}$ & & & & & & & & \\
\hline- & підйом переворотом в упор самостійно. & & & & & & & & & $\mathrm{H}$ & $\mathrm{H}$ & K & & & & & \\
\hline- & навчальна комбінація & & & & & & & & & 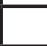 & & & п & п & п & К & K \\
\hline & Бруси: & & & & & & & & & & & & & & & & \\
\hline & з упору на руках підйом махом вперед & & & & & + & + & + & + & + & + & + & + & + & + & + & \\
\hline- & розмахування в упорі; & & & & & $\Pi$ & п & $\Pi$ & $\Pi$ & $\Pi$ & п & п & $\Pi$ & $\Pi$ & $\Pi$ & $\Pi$ & \\
\hline- & упор на руках з провисанням; & & & & & $\Pi$ & п & & & & & & & & & & \\
\hline- & розмахування в упорі на руках; & & & & & $\Pi$ & $\Pi$ & $\Pi$ & п & п & п & п & п & п & п & п & \\
\hline- & розмахування в упорі на руках по заданій амплітуді; & & & & & & $\mathrm{H}$ & $\Pi$ & & & & & & & & & \\
\hline- & $\begin{array}{l}\text { розмахування в упорі на руках з мінімальним збільшен- } \\
\text { ням маху вперед; }\end{array}$ & & & & & & & $\mathrm{H}$ & п & $\Pi$ & & & & & & & \\
\hline- & $\begin{array}{l}\text { розмахування в упорі на руках з підльотом і мінімаль- } \\
\text { ним збільшенням маху вперед; }\end{array}$ & & & & & & & & H & $\mathrm{H}$ & п & п & п & п & $\Pi$ & & \\
\hline- & з упору на зігнутих руках підйом махом вперед; & & & & & & & & & & $\mathrm{H}$ & & & & & & \\
\hline- & з упору на передпліччях підйом махом вперед; & & & & & & & & & & $\mathrm{H}$ & п & $\Pi$ & & & & \\
\hline- & $\begin{array}{l}\text { на похилих брусах підйом махом вперед у сід ноги наріз- } \\
\text { но; }\end{array}$ & & & & & & & & & & & $\mathrm{H}$ & п & & & & \\
\hline- & підйом махом вперед з допомогою; & & & & & & & & & & & & $\mathrm{H}$ & $\Pi$ & & & \\
\hline- & підйом махом вперед самостійно; & & & & & & & & & & & & & $\mathrm{H}$ & $\mathrm{H}$ & K & \\
\hline- & підйом махом вперед і зіскок махом назад. & & & & & & & & & & & & & & $\mathrm{H}$ & $\mathrm{H}$ & \\
\hline & Навчальна комбінація & & & & & & & & & & & & & $\Pi$ & $\Pi$ & K & К \\
\hline & Дівчата & & & & & & & & & & & & & & & & \\
\hline & Різновисокі бруси: & & & & & & & & & & & & & & & & \\
\hline- & $\begin{array}{l}\text { вис прогнувшись на н.ж., упираючись стопами об в.ж., } \\
\text { перехід в упор на н.ж.; }\end{array}$ & & & & & H & H & $\mathrm{H}$ & п & п & п & п & п & п & п & $\Pi$ & \\
\hline- & $\begin{array}{l}\text { махом одною і поштовхом другою підйом переворотом } \\
\text { в упор на н.ж.; }\end{array}$ & & & & & $\Pi$ & п & $\Pi$ & п & $\Pi$ & п & п & $\Pi$ & п & п & К & \\
\hline- & зіскок з сіду на стегні. & & & & & $\mathrm{H}$ & $\Pi$ & $\Pi$ & п & п & $\Pi$ & $\Pi$ & п & п & п & К & \\
\hline & Навчальна комбінація. & & & & & & & & & & & п & п & п & п & К & к \\
\hline 5 & Вирави в рівновазі на підлозі: & + & + & + & + & & & & & & & & & & & & \\
\hline- & підскоки на одній нозі; & + & + & + & + & & & & & & & & & & & & \\
\hline- & напівприсід; & + & + & + & + & & & & & & & & & & & & \\
\hline- & сід кутом; & + & + & + & + & & & & & & & & & & & & \\
\hline- & поворот в присіді; & + & + & + & + & & & & & & & & & & & & \\
\hline- & зіскок з напівприсіда. & + & + & + & + & & & & & & & & & & & & \\
\hline & На лаві: & & & & & & & & & & & & & & & & \\
\hline- & підскоки на одній нозі; & & + & + & + & & & & & & & & & & & & \\
\hline- & напівприсід; & & + & + & + & & & & & & & & & & & & \\
\hline- & сід кутом; & & + & + & + & & & & & & & & & & & & \\
\hline- & поворот в присіді; & & + & + & + & & & & & & & & & & & & \\
\hline- & зіскок з напівприсіда. & & + & + & + & & & & & & & & & & & & \\
\hline
\end{tabular}




\begin{tabular}{|c|c|c|c|c|c|c|c|c|c|c|c|c|c|c|c|c|c|}
\hline № & Номери уроків & 17 & 18 & 19 & 20 & 21 & 22 & 23 & 24 & 25 & 26 & 27 & 28 & 29 & 30 & 31 & 32 \\
\hline & Вправи на колоді: & & & & & & & & & & & & & & & & \\
\hline- & підскоки на одній нозі; & & & + & + & & & & & & & & & & & & \\
\hline- & напівприсід; & & & + & + & & & & & & & & & & & & \\
\hline- & сід кутом; & & & + & + & & & & & & & & & & & & \\
\hline- & поворот в присіді; & & & + & + & & & & & & & & & & & & \\
\hline \multirow[t]{2}{*}{-} & зіскок з напівприсіда. & & & + & + & & & & & & & & & & & & \\
\hline & Навчальна комбінація. & & & & & & & & п & п & п & п & $\Pi$ & $\Pi$ & $\Pi$ & $\Pi$ & п \\
\hline \multirow[t]{3}{*}{6} & Акробатичні вправи: & & & & & & & & & & & & & & & & \\
\hline & Юнаки & & & & & & & & & & & & & & & & \\
\hline & стійка силою на голові і руках & & & & & + & + & + & + & + & + & + & & & & & \\
\hline- & $\begin{array}{l}3 \text { упору стоячи зігнувшись спиною до гімнастичної } \\
\text { стінки перехід у вис прогнувшись; }\end{array}$ & & & & & п & п & $\Pi$ & $\Pi$ & & & & & & & & \\
\hline- & $\begin{array}{l}\text { з упору присівши обпертися головою об мат на розмітку } \\
\text { i рівномірно передати вагу тіла на руки і голову }\end{array}$ & & & & & & & & H & п & п & & & & & & \\
\hline- & $\begin{array}{l}\text { те саме, але, піднімаючи ноги від підлоги і утримуючи їх } \\
\text { зігнутими, випрямити спину; }\end{array}$ & & & & & & & & & H & н & п & & & & & \\
\hline- & $\begin{array}{l}\text { стійка на голові і руках самостійно з опорою спиною і но- } \\
\text { гами об стінку; }\end{array}$ & & & & & & & & & & н & н & $\Pi$ & & & & \\
\hline \multirow[t]{2}{*}{-} & стійка на голові і руках. & & & & & & & & & & & & $\mathrm{H}$ & $\mathrm{H}$ & K & & \\
\hline & Довгий перекид з трьох кроків & & & & & & & & & & & & & & & & \\
\hline- & перекид вперед з різною швидкістю; & & & & & п & п & п & п & & & & & & & & \\
\hline- & перекид з розбігу на горку матів; & & & & & & & $\mathrm{H}$ & $\mathrm{H}$ & п & п & & & & & & \\
\hline \multirow[t]{3}{*}{-} & перекид вперед через мотузку. & & & & & & & & & $\mathrm{H}$ & н & $\mathrm{H}$ & $\mathrm{H}$ & K & & & \\
\hline & Навчальна комбінація & & & & & & & & & & 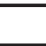 & & $\Pi$ & п & $\Pi$ & К & к \\
\hline & Дівчата & & & & & & & & & & & & & & & & \\
\hline- & рівновага на одній нозі, випад уперед; & & & & & п & п & п & п & п & п & п & $\Pi$ & $\Pi$ & & & \\
\hline- & перекиди уперед, назад; & & & & & п & $\Pi$ & п & п & п & п & п & $\Pi$ & $\Pi$ & & & \\
\hline- & «міст» і поворот в упор стоячи на колінах; & & & & & п & п & п & $\Pi$ & п & п & п & $\Pi$ & п & & & \\
\hline \multirow[t]{2}{*}{-} & перекид назад в напівшпагат. & & & & & п & п & $\Pi$ & $\Pi$ & п & п & п & $\Pi$ & $\Pi$ & & & \\
\hline & Навчальна комбінація & & & & & & & & & & - & & $\Pi$ & п & $\Pi$ & K & K \\
\hline \multirow[t]{3}{*}{7} & Опорний стрибок & & & & & & & & & & & & & & & & \\
\hline & Юнаки & & & & & & & & & & & & & & & & \\
\hline & стрибок зігнувши ноги (козел в довжину, $h=115 \mathrm{~cm})$ & & & & & + & + & + & + & + & + & + & + & + & + & + & \\
\hline- & $\begin{array}{l}\text { з упору лежачи поштовхом ніг упор присівши і в темп упор } \\
\text { лежачи; }\end{array}$ & & & & & H & п & п & $\Pi$ & п & п & п & п & & & & \\
\hline- & $\begin{array}{l}\text { з упору лежачи поштовхом ніг упор присівши і в темп } \\
\text { встати, руки вверх-назовні; }\end{array}$ & & & & & & $\mathrm{H}$ & п & $\Pi$ & $\Pi$ & п & п & $\Pi$ & & & & \\
\hline- & $\begin{array}{l}\text { з упору лежачи одночасним поштовхом руками і ногами } \\
\text { присід, руки вперед; }\end{array}$ & & & & & & & $\mathrm{H}$ & $\Pi$ & $\Pi$ & п & п & п & & & & \\
\hline- & $\begin{array}{l}\text { вскок в упор присівши на козла в ширину і в темпі зіскок } \\
\text { уперед прогнувшись }(\mathrm{h}=1 \text { м); } 3 \text { розбігу } 3 \text { м вскок в упор } \\
\text { присівши на козла і в темпі зіскок зігнувши ноги; }\end{array}$ & & & & & & & & & & & & п п & п п & & & \\
\hline- & $\begin{array}{l}\text { з упору присівши, руки на лаві, стрибок зігнувши ноги } \\
\text { через гімнастичну лаву; }\end{array}$ & & & & & & & & & & & & $\bar{\Pi}$ & п & $\Pi$ & & \\
\hline- & $\begin{array}{l}\text { 3 5-7 кроків розбігу стрибок зігнувши ноги через козла } \\
\text { в ширину; }\end{array}$ & & & & & & & & & & & & $\Pi$ & п & $\Pi$ & & \\
\hline \multirow[t]{3}{*}{-} & $\begin{array}{l}\text { з розбігу стрибок зігнувши ноги через козла в довжину } \\
(\mathrm{h}=115 \mathrm{~cm})\end{array}$ & & & & & & & & & & & & $\mathrm{H}$ & $\mathrm{H}$ & $\mathrm{H}$ & $\mathrm{H}$ & к \\
\hline & Дівчата & & & & & & & & & & & & & & & & \\
\hline & стрибок боком (кінь в ширину, $h=110$ см) & & & & & & & & & & & & & & & & \\
\hline- & настрибнути на коня в упор боком вправо (вліво); & & & & & п & п & & & & & & & & & & \\
\hline- & стрибок боком, упираючись одною ногою об коня; & & & & & п & п & & & & & & & & & & \\
\hline- & стрибок боком з розбігу. & & & & & $\Pi$ & $\Pi$ & $\Pi$ & п & п & п & п & $\Pi$ & $\Pi$ & $\Pi$ & $\Pi$ & K \\
\hline 8 & Вправи для розвитку рухових здібностей: & & & & & & & & & & & & & & & & \\
\hline- & з упору на руках ривком упор; & + & + & + & + & & & & & & & & & & & & \\
\hline- & згинання-розгинання рук в упорі на швидкість; & + & + & + & + & & & & & & & & & & & & \\
\hline- & згинання-розгинання рук в упорі; & + & + & + & + & & & & & & & & & & & & \\
\hline- & згинання-розгинання рук у висі. & + & + & + & + & & & & & & & & & & & & \\
\hline 9 & Контрольні вправи & & & & & & & & & & & & & & & K & к \\
\hline
\end{tabular}


і третя серії в такому ж порядку, але з підвищеною трудністю і інтенсивністю, із завданнями оцінювати амплітуду, швидкість і ступінь м'язових зусиль. Така послідовність вправ забезпечує поступове збільшення навантаження і зміну роботи різноманітних груп м'язів, що підвищує ефективність м'язових зусиль і створює умови для активного відпочинку працюючих м'язів.

4. Далі в комплекс включаються 2-3 вправи для всіх частин тіла з різною інтенсивністю.

5. В кінці комплексу повинні бути вправи помірної інтенсивності спрямовані на навчання диханню. Закінчуватися повинен комплекс вправою на відчуття правильної постави.

Кожну вправу в комплексі слід повторювати від 4 до 8 раз, вправи для розвитку сили повинні передувати вправам на гнучкість і повторюватися до відчуття втоми тих груп м'язів, що виконують роботу, а вправи на гнучкість - до появи легких болючих відчуттів.

\section{Комплекс № 1 (роздільний спосіб)}

1. В. п. - о. с., стоячи в шеренгу.

1. Крок правою в сторону, руки уперед.

2. Приставити ліву, руки униз.

2. В. п. - о. с., стоячи в колону.

1. Крок лівою вперед.

2. Приставити праву.

3. Упор присівши.

4. В. п.

3. В. п. - стійка ноги нарізно, руки в сторони, стоячи в шеренгу.

1. Нахил уперед, руки уперед.

2. Випрямляючись поворот направо кругом у в. п. $3-4$. Те саме, але з поворотом в іншу сторону.

4. В. п. - руки назад, стоячи в колону.

1. Крок лівою уперед, руки уверх.

2. Приставляючи праву, нахил уперед, руки назад.

3. Випрямитися, крок лівою уперед, руки уверх.

4. Приставляючи праву в. п.

5. В. п. - руки в сторони, стоячи в шеренгу.

1. Крок правою в сторону, нахил вліво, руки за голову.

2. Приставляючи ліву в. п.

6. В. п. - руки уперед-назовні, долонями униз, стоячи в колону.

1. Однойменний мах лівою, торкнутися лівої руки.

2. Крок лівою.

3-4. Те саме правою.

7. В. п. - руки на поясі, стоячи в колону.

1-4. Стрибки на двох, з просуванням уперед.
5-8. Послідовними стрибками поворот наліво на $360^{\circ}$.

9-16. Те саме з поворотом в іншу сторону.

Біг і ходьба в обхід.

\section{Комплекс № 2 (прохідний спосіб, 1 варіант)}

1. В. п. - руки за спиною.

$1-4$. Ходьба на носках.

5-8. Ходьба звичайним кроком.

9-16. Те саме, але на п'ятках.

2. В. п. - руки на поясі.

$1-8$. Нахили голови уперед та назад.

9-16. Те саме в сторони.

3. В. п. - руки унизу.

1-4. Повільний присід, руки на коліна.

5-8. В. п.

4. В. п. - руки упереді.

1. Ривком руки в сторони.

2. В. п.

3. Ривком руки уверх.

4. В. п.

5. В. п. - руки унизу-ззаду, пальці з’єднані.

1. Ривком руки назад, прогнутися.

2. В. п.

6. В. п. - руки до плечей.

1. Поворот тулуба наліво, руки уверх.

2. В. п.

3-4. Те саме вправо.

7. В. п. - руки за головою.

1. Нахил вліво, ліву руку в сторону, долонню уверху.

2. В. п.

3-4. Те саме вправо.

8. В. п. - руки уверху.

1. Однойменний мах лівою, руки уперед-назовні, долонями униз.

2. Крок лівою, руки уверх.

3-4. Те саме правою.

9. В. п. - ліва рука на поясі, права - в сторону.

1. Стрибком стійка ноги нарізно, змінити положення рук.

2. Стрибком стійка ноги разом, змінити положення рук.

Біг і ходьба в обхід.

\section{Комплекс № 3}

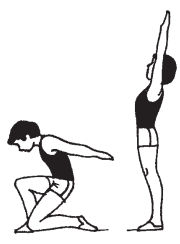

1. В. п. - стоячи на лівому коліні, руки назад, голова на грудях.

1. Встати, руки уверх, прогнутися.

2. В. п.

Повторити 4-8 раз. 


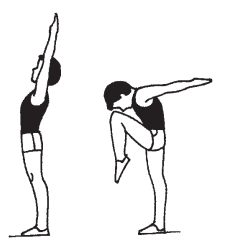

2. В. п. - руки уверх долонями уперед, прогнутися.

$1-2$. Підняти уперед зігнуту ліву ногу i, нахиляючи голову уперед, торкнутися чолом коліна, руки опустити уперед і відвести назад.

3-4. В. п.

5-8. Те саме з іншої ноги. Повторити 4-8 раз.

3. В. п. - упор стоячи на колінах.

1. Зігнути руки, голову повернути наліво.

2. В. п.

3-4. Те саме в іншу сторону.

Повторити 4-8 раз.

4. В. п. - упор лежачи.

1. Ліву ногу назад і з поворотом таза опустити іiі за правою ногою.

2. В. п.

3-4. Те саме з іншої ноги.

Повторити $4-8$ раз.

5. В. п. - упор лежачи боком на лівій, права на поясі.

1. Сід на лівому стегні.

2. В. п.

Те саме правим боком. Повторити 4-8 раз.

6. В. п. - основна стійка.

1. Зігнути ліву ногу уперед.

2. Відвести їі в сторону.

3. Випрямляючи, мах лівою ногою назад.

4. В. п.

5-8. Те саме правою ногою.

Повторити 4-8 раз.

7. В. п. - упор сидячи ззаду.

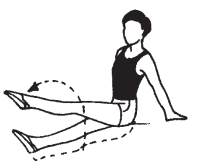

1. Ліву ногу уперед.

2. Опустити іï вправо, торкнувшись підлоги.

3. Ліву ногу уперед.

4. В.

5-8. Те саме з правої ноги.

Повторити 8 раз.

8. В. п. - лежачи на спині, руки вздовж тіла.

$1-2$. Підняти прямі ноги 3 торканням носками підлоги за головою.

3-4. В. п.

Повторити 4-8 раз.

9. В. п. - руки на поясі.

1. Присісти на лівій, права уперед, руки на поясі («пістолет»).

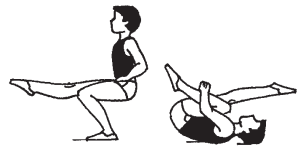

2. Перекат назад - руками обхопити ліву ногу.

3. Присід на лівій, права пряма уперед, руки на поясі («пістолет»).

4. В. п.

Повторити 4 рази.

10. В. п. - основна стійка.

1. Махом лівою уперед, поворот кругом, руки уверх, ліву на носок ззаду.

2. Випад лівою назад руки уперед.

3. Стійка на правій, ліву на носок ззаду, руки уверх.

4. В. п.

5-5. Те саме махом правої ноги.

Повторити 4 рази.

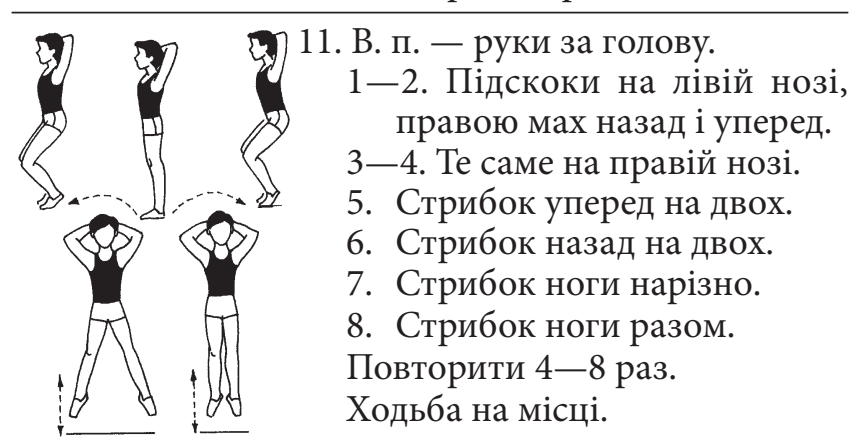

Комплекс № 4. Вправи в парах

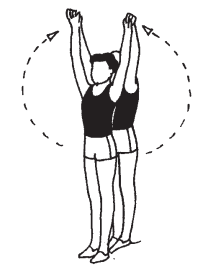

1. В. п. - стоячи друг за другом, руки внизу з'єднані.

1. А - стоїть попереду, піднімає руки через сторони уверх, Б - чинить опір.

2. Руки униз.

Повторити 4 рази.

2. В. п. - стійка ноги нарізно стоячи обличчям один до одного, руки прямі на плечах партнера.

1-3. Пружні нахили вліво.

4. В. п.

5-8. Те саме в іншу сторону. Партнери взаємно підсилюють нахили.

Повторити 8 раз.

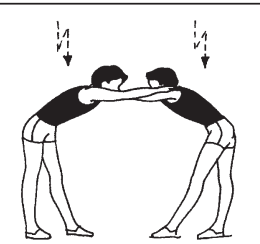

3. В. п. - стоячи обличчям один до одного, стійка ноги нарізно лівою, нахил уперед, руки прямі на плечах партнера.

1-3. Пружні нахили уперед, взаємний опір. 
4. Стрибком зміна положення ніг - в. п.

Повторити 8 раз.

4. В. п. - А - стійка ноги нарізно, руки уверх, пальці з'єднані; Б - стоїть збоку, стійка ноги нарізно, ліву руку на талію партнера, правою тримає за кисть А.

1. А - нахил назад, Б - підсилює нахил.

2. В. П.

Повторити 8 раз.

5. В. п. - стоячи обличчям один до одного, руки уперед, тримаючи за кисті партнера.

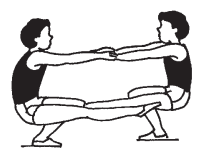
1-2. Присід на лівій нозі, праву уперед («пістолет»).

3-4. В. п.

Повторити 8 раз. Те саме на іншій нозі.

6. В. п. - стоячи обличчям один до одного, тримаючись за руки, руки вправо.

1. Мах лівою ногою упередвправо, руки вліво.

2. В. П.

3-4. Те саме з іншої ноги.

Повторити 12 раз.

7. В. п. - А - сидить на підлозі, руки за головою пальці з'єднані. Б - стоїть за спиною в стійці ноги нарізно, нахиляючись уперед, руки під лопатки А.
1. Встати з допомогою партнера, прогинаючись.

2. В. п.

Повторити 8 раз.

8. В. п. - сід ноги нарізно, упираючись ступнями, тримаючись за руки.

1-4. Кружіння тулуба вліво.

5-8. Кружіння тулуба вправо. Повторити 4 рази.

9. В. п. - А - лежачи на спині, руки уверх; Б - упор лежачи з боку голови, упираючись в груди партнера (дівчата в плечі).

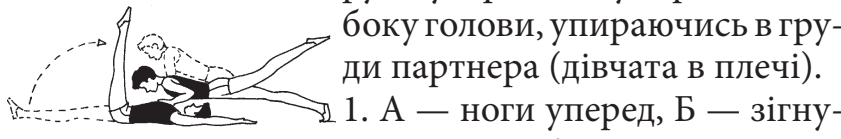
ти руки, ліву назад.

2. В. п.

Повторити 8 раз.

10. В. п. - стоячи на колінах спиною один до одного, упираючись ступнями ніг, тримаючись за руки.

1. Прогнутися.

2. В. п.

Повторити 8 раз.

11.В. п. - стоячи один за одним; А - руки на пояс, Б - руки на плечі партнера.

1-4. А - стрибки на одній 3 опором.

5-8. А - стрибки на двох 3 опором.

Ходьба на місці.

\section{Упорядковуємо конспекти уроків}

На основі завдань уроків (див. табл. 2) і тематичного плану- графіка упорядковуємо конспекти уроків (див. табл. 3).

\section{Приклад орієнтовного конспекту уроку:}

Конспект уроку № 23 по фізичній культурі для учнів 9-х класів

Завдання уроку:

Юнаки:

1. Сприяти розвитку спеціальної рухової підготовленості учнів.

2. Навчити підйому махом вперед: друга і третя серії навчальних завдань.

Дівчата:

1. Навчити вису прогнувшись на н.ж., з опорою стопами об в.ж. і переходу в упор на н.ж.

2. Повторити акробатичні вправи.

3. Повторити стрибок боком.

\begin{tabular}{|l|l|l|c|c|}
\hline \multirow{2}{*}{ 3міст } & \multicolumn{3}{|c|}{$\begin{array}{c}\text { Оозування } \\
\text { Організаційно- } \\
\text { методичні } \\
\text { вказівки }\end{array}$} \\
\cline { 3 - 5 } & $\begin{array}{c}\text { Кількість } \\
\text { підходів }\end{array}$ & $\begin{array}{c}\text { Кількість } \\
\text { повто- } \\
\text { рень }\end{array}$ & $\begin{array}{c}\text { Час } \\
\text { відпо- } \\
\text { чинку }\end{array}$ & \\
\hline Підготовча частина & & & & \\
\hline
\end{tabular}




\begin{tabular}{|c|c|c|c|c|}
\hline Шикування, рапорт, повідомлення задач уроку. & & & & \\
\hline \multicolumn{5}{|l|}{ Стройові вправи. } \\
\hline $\begin{array}{l}\text { Загальнорозвиваючі вправи: } \\
\text { комплекс № } 1 \\
\text { комплекс № } 3 \\
\end{array}$ & & & & $\begin{array}{l}\text { Слідкувати за гімнастичним стилем ви- } \\
\text { конання. }\end{array}$ \\
\hline \multicolumn{5}{|l|}{$\begin{array}{l}\text { Основна частина } \\
\text { Юнаки: СФП: } \\
\text { 1. Вправи для м ‘язів рук, спини і ніг: }\end{array}$} \\
\hline — $з$ упору лежачи поштовхом ніг упор присівши; & 1 & 5 & 40 & Виконувати максимально швидко. \\
\hline $\begin{array}{l}\text { - } 3 \text { упору лежачи поштовхом ніг упор присівши і в } \\
\text { темп встати, руки вверх-назовні; }\end{array}$ & 1 & 5 & 40 & \\
\hline $\begin{array}{l}\text { - } \text { з упору лежачи одночасним поштовхом руками і } \\
\text { ногами присід, руки уперед; }\end{array}$ & 2 & 5 & 40 & \\
\hline $\begin{array}{l}\text { - } 3 \text { упору стоячи зігнувшись спиною до гімнастич- } \\
\text { ної стінки, перехід у вис прогнувшись, з опором; }\end{array}$ & 1 & 3 & 40 & Опір чинить партнер, стоячи з боку. \\
\hline — те саме, без опору з двома зупинками; & 1 & 5 & 40 & Суглобні кути фіксувати 5 сек. \\
\hline - те саме, в звичайному темпі. & 1 & 8 & 40 & \\
\hline \multicolumn{5}{|l|}{ 2. Вправи для м'язів рук і тулуба: } \\
\hline - згинання-розгинання рук у висі; & 1 & 5 & 40 & Виконувати швидко. \\
\hline - те саме, з опором; & 1 & 3 & 40 & $\begin{array}{l}\text { Виконувати з максимальними зусил- } \\
\text { лями. }\end{array}$ \\
\hline - вис на зігнутих руках, вис прогнувшись; & 1 & 3 & 40 & Фіксувати суглобні кути 5 сек. \\
\hline - $з$ положення лежачи на перекладині, упор. & 1 & 8 & 40 & Виконувати у звичайному темпі. \\
\hline \multicolumn{5}{|l|}{ Бруси: } \\
\hline - розмахування в упорі; & 1 & 6 & 40 & $\begin{array}{l}\text { Вправи виконувати у гімнастичному } \\
\text { стилі. }\end{array}$ \\
\hline - упор на руках з провисанням; & 1 & 3 & 40 & \\
\hline - розмахування в упорі на руках; & 1 & 6 & 40 & \\
\hline $\begin{array}{l}\text { - розмахування в упорі на руках по заданій амплі- } \\
\text { туді; }\end{array}$ & 1 & 6 & 40 & Використовувати додаткові орієнтири. \\
\hline $\begin{array}{l}\text { - розмахування в упорі на руках з мінімальним } \\
\text { збільшенням маху вперед. }\end{array}$ & 3 & 6 & 40 & Уміти збільшити мах 5-6 раз. \\
\hline \multicolumn{5}{|l|}{ Акробатика: } \\
\hline - перекиди вперед; & 5 & 3 & 30 & Виконувати з різною швидкістю. \\
\hline - перекид вперед з розбігу на горку матів. & 6 & 1 & 20 & \\
\hline \multicolumn{5}{|l|}{$\begin{array}{l}\text { Дівчата: } \\
\text { Бруси: }\end{array}$} \\
\hline $\begin{array}{l}\text { - вис прогнувшись на н.ж., спираючись стопами об } \\
\text { в.ж., перехід в упор на н.ж. }\end{array}$ & 3 & 3 & 60 & Виконувати з допомогою і самостійно. \\
\hline $\begin{array}{l}\text { — махом одною і поштовхом другою підйом пере- } \\
\text { воротом в упор; }\end{array}$ & 6 & 2 & 60 & \\
\hline - зіскок з сіду на стегні. & 3 & 3 & 60 & \\
\hline \multicolumn{5}{|l|}{ Акробатика: } \\
\hline - рівновага на одній нозі, випад уперед; & 6 & 3 & 20 & $\begin{array}{l}\text { Акробатичні вправи виконувати ви- } \\
\text { користовуючи фронтальний метод ор- } \\
\text { ганізації учнів. }\end{array}$ \\
\hline - «міст» і поворот в упор стоячи на колінах; & 5 & 3 & 2 & \\
\hline - перекид назад у напівшпагат; & 6 & 3 & 20 & \\
\hline \multicolumn{5}{|l|}{ Опорний стрибок: } \\
\hline - настрибнути на коня в упор боком вправо; & 3 & 1 & 20 & Стрибки виконувати зі страховкою. \\
\hline $\begin{array}{l}\text { - стрибок боком, упираючись одною ногою об } \\
\text { коня; }\end{array}$ & 3 & 1 & 20 & \\
\hline - стрибок боком. & 3 & 1 & 20 & \\
\hline \multicolumn{5}{|l|}{ Заключна частина } \\
\hline $\begin{array}{l}\text { Ходьба, біг. } \\
\text { Шикування, підсумок заняття. } \\
\text { Домашнє завдання } \\
\end{array}$ & & & & \\
\hline
\end{tabular}




\section{Список літератури}

1. Васьков Ю.В., Пашков І.М. Уроки фізкультури в загальноосвітній школі. 1-4 класи (102 уроки для кожного класу). - Харків: Торсінг, 2003. - 208 с.

2. Васьков Ю.В., Пашков I.М. Уроки фізкультури в загальноосвітній школі. 5-9 класи (102 уроки для кожного класу). - Харків: Торсінг, 2003. - 288 с.

3. Васьков Ю.В., Пашков І.М. Уроки фізкультури в загальноосвітній школі. 10-11 класи (102 уроки для кожного класу). - Харків: Торсінг, 2003. - 256 с.

4. Гимнастика. Учебник для техникумов физической культуры / Под ред. М.Л. Украна и А.М. Шлемина. - М.: Физкультура и спорт, 1977.

5. Гимнастика. Учебник для ин-тов физ. культ. - Изд. 2-е / Под ред. А.М. Шлемина и А.Т. Брыкина. - М.: Физкультура и спорт, 1979.

6. Гимнастика. Учебник для техникумов физической культуры / Под ред. А.Т. Брыкина и В.М. Смолевского. - М.: Физкультура и спорт, 1985.
7. Гимнастика и методика преподавания: Учебник для институтов физической культуры / Под ред В.М. Смолевского. - Изд. 3-е, перераб., доп. - М.: Физкультура и спорт, 1987.

8. Дубовис М.С., Цвек С.Ф. Планування навчальної роботи з фізичної культури в 5-11 класах: Метод. рек. - К.: Пед. преса, 1999. - 164 с.

9. Лящик Р.П., Огнистий А.В. Гімнастика. Навчальний посібник (у двох частинах). - Ч. 2. - Тернопіль: ТДПУ, 2001.

10. Петров П.К. Методика преподавания гимнастики в школе: Учеб. для студ. высш. учеб. заведений. - М.: Гуманит. изд. центр ВЛАДОС, 2000.

11. Худолій О.М. Основи методики викладання гімнастики. Навчальний посібник. В 2-х частинах. - 3-є вид., випр. і доп. - Харків: ОВС, 2004. - Ч. 1. - 414 C.

12. Худолій О.М. Основи методики викладання гімнастики. Навчальний посібник / Харк. держ. пед. ун-т ім. Г.С. Сковороди. - Т. 2. - Х.: Консум, 1998.

Надійшла до редакиії 26.01.2008 p.

Худолей О.Н. Методика планирования учебной работы по гимнастике в школе.

В статье раскрытая методика планирования учебной работы по гимнастике в школе. Сформулированные основные требования к упорядочению документации.

Ключевые слова: планирование, документы, гимнастика.

Houdoliy O.M. Method of planning of educational work from gymnastics at school.

In article exposed method of planning of educational work from gymnastics at school. Formulated basic vimogo to organization of document.

Keywords: planning, documents, gymnastics.

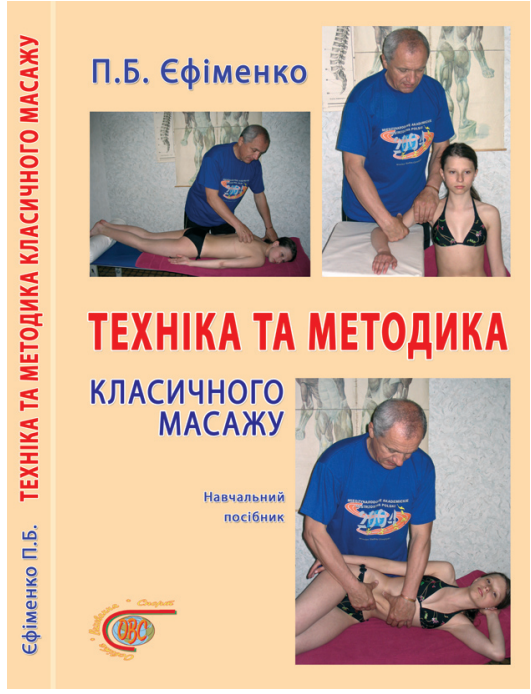

\section{Єфіменко П.Б.}

E91 Техніка та методика класичного масажу. - Харків: «ОВС», 2007. $-216 \mathrm{c}$

ISBN 966-7858-49-9.

Навчальний посібник вміщує докладний опис техніки виконання основних та додаткових масажних прийомів. Детально описано методику масажу окремих частин тіла людини з точки зору процедури загального гігієнічного масажу. Значна увага приділяється спрямованості механічної дії окремих прийомів, що сприятиме більш чіткому диференціюванню структури часткового масажу з урахуванням анатомічної побудови масажованої ділянки тіла. Автором зроблено спробу уніфікувати термінологію щодо назв окремих масажних прийомів.

Розділи зі спортивного та лікувального масажу вміщують необхідний методичний матеріал для роботи як у спортивній команді, так і лікувальних установах.

Навчальний посібник розрахований на студентів та викладачів вищих навчальних закладів де викладається масаж, а також для тренерів, реабілітологів і масажистів різного профілю. 